\title{
The Jaded Gender and Development Paradigm of Egypt
}

\author{
Hania Sholkamy
}

\begin{abstract}
The people's solidarity in search for rights, dignity and justice in the days of the uprising against Mubarak's regime challenged the assumptions guiding the gender and development paradigm. Women who participated in their thousands trod very different paths from those engineered by gender and development policy advocates, about how to support women to engage politically. It highlighted more than ever, the limitations of previous approaches that supported an apolitical gender and development agenda in an authoritarian regime. This article argues that in post-revolutionary Egypt, gendered work is no longer the exclusive realm of development and is expressing itself differently, through political party activism and religious philanthropy charity. The extent to which a gender equality agenda will develop forcefully will depend on the nature of the state system, the extent to which there will be avenues for political engagement outside development, and the extent to which philanthropic organisations will assume centre stage in engaging with women's needs as religious subjects.
\end{abstract}

\begin{abstract}
1 August 2011
The Egyptian revolution exposed the deficiencies of development policies as it toppled the Egyptian regime. This people's movement espoused the values of rights, dignity and democracy that are the same principles that inform the rights-based development paradigm and ensuing programmes, and which have been strongly propagated in Egypt for many years, with little resonance among the public. This article considers the implications of what we know of this Egyptian revolution to the paradigm of human development and to its modes of operation and funding, by focusing specifically on questions of women's empowerment and gender equity.
\end{abstract}

For decades, development paradigms and programmes have adopted the values of human wellbeing and dignity, which are both profoundly political projects, while at the same time pretending that development is an apolitical venture. This paradox is evinced by the ability of development practitioners to claim that their rights-driven programmes have had impacts and successes even when these self-same programmes existed in the midst of autocratic and unjust polities. Egypt is a contentious and critical case in point. There is a blurred divide between development as a process that is respectful of sovereignty, even if it is externally funded, and as an intervention that is enabling Egyptians to challenge state hegemony (Mitchell 1995).

Gender and development programmes provide an illustration of such contradictions in practice. On the one hand, the Egyptian state was party to most relevant universal declarations and conventions on gender rights and equality. On the other hand, the space to claim these rights was constricted by a state-led hegemony over civilian and public spaces. Meanwhile, development agents, funders and practitioners were lost between the micro-level at which their programmes seemed to work and were defined as apolitical spaces, and the macro-political level at which the only changes were those effected by state fiat and not by citizen actions. Despite the many seemingly successful projects on the ground on the micro-level, and the seemingly progressive initiatives of state elites on the macro-level, gender justice remained ever elusive. Yet the revolution represented a disconnect with the status quo, albeit temporary. The equality agenda after the revolution, it will be argued, is up for grabs and is concomitant on a number of integral factors. 


\section{The people's moment}

There were whole families, including small children and their mothers, sleeping in Tahrir Square during 28 January-11 February 2011 and there were hundreds, if not thousands, of women involved in organising supplies, medication, banners, marches, international contacts and general mobilisation for this movement. The array of dress codes during those days in so many squares and cities in Egypt was in itself telling. There were veiled women who covered their face, or just their hair or appeared unveiled. There were women alone, with children, the very young and the elderly all standing in solidarity together. The involvement of workers, Muslim Brothers, liberals, leftists and even men and women who had no political creed of any kind pointed to the vibrant people's solidarity that was a feature of the protests that consolidated a revolution in Egypt.

Women's significant participation as described above has, perhaps inadvertently, discredited formal politics and the development programmes that have sought to make it the exclusive focus of their interventions to empower women politically. This critical role played by women as bloggers, as activists, as protestors, as voices of anger and discontent, contrasts deeply with the labours of gender justice bureaucracies, whether para-governmental or non-governmental, to involve women in politics. The narrative on voice and women's empowerment spoken in the language of development was all about parliamentary quotas and the necessity of 'creating' local women leaders who could contest elections and then, by winning seats in councils or parliaments, participate in politics and make the process less patriarchal. Women's political engagement and their collective action are items on a development agenda that seeks to give women 'voice' and achieve the political empowerment of women (Goetz and Nyamu 2008). Some have analysed the nature and patterns of women's engagement in social movements, different mobilisation strategies used by feminists in their engagement with the state and the impact of transnational linkages on feminist movement (Batliwala 2010).

This literature that espouses collective action as an avenue to empowerment is not developmental but feminist in its origins. However, a development formula focused on state-based arrangements can ensure women's representation in legislative and executive bodies and consequently, pursue a policy of introducing quotas and shattering glass ceilings. This logic may at some level be sound but the 60 or so women who had just 'won' parliamentary seats in December 2010 were discredited by the events of January 2011 and so was the assumption that women leaders had to be 'trained' to engage politically. The women on the squares of Egypt decimated the work on 'voice' and women's political participation enacted in programmes initiated by the National Council for Women led by the First Lady and by various non-governmental organisations (NGOs).

Quotas in a rigged election, access to high office in the absence of transparency and accountability, local council representation without good governance or voice without freedom do not deliver gender justice. The recommended recipes that are the agendas of development programmes fade when faced with a mass quest for dignity and choice.

\section{The post-Mubarak reality}

When the President of Egypt was ousted from power on 11 February, the whole country began a transition to an unknown territory called 'democracy'. It was on 8 March that the problems of gender injustices resurfaced when women's groups and individuals went to downtown Cairo and to Tahrir Square to commemorate International Women's Day and were attacked and hounded out of the square that was supposed to be the 'labour ward' in which democracy had been reborn in Egypt.

Meanwhile, calls to repeal all of the gains made for women in the past decades resounded in the media and in legal courts. The National Council for Women led by Mrs Mubarak had indeed participated in realising the changes that women activists had called for; changes that are in-line with the principles of international covenants and conventions such as the Committee on the Elimination of Discrimination against Women (CEDAW). The rights to mobility, political representation as a fixed quota, unilateral divorce, and the criminalisation of female genital mutilations were all 'wins' made under authoritarianism. A leading judge who had presided over the family courts created to realise a fairer judicial process for children and women in cases of divorce, became the leading anti- 
family courts proponent. A new civil society organisation for 'Family Protection' came into being under his auspices and is calling for a repeal of the right for women to unilateral divorce (known as 'Khol'), reducing the age of custody to seven years, after which the father has automatic guardianship of children ${ }^{1}$ and the return of the institution of 'beit el Ta' $a$ ' whereby the police can force women who wish to leave the marital home to return to the husband! Sharmani (2011) has rejected claims that the laws that deny women their rights and dignity are grounded in religious principles or traditions. She argues that the current debate has elided Fiqh and Sharia so as to make the interpretations of scholars the same as the eternal principles suggested by the Sharia as a basis for jurisprudence. In other words, Sharmani argues that the U-turn in terms of personal status laws, if it happens, will reflect patriarchal and not sacred choices!

The successive ministerial cabinets formed since 11 February have only one female minister, a stalwart of the past and current regimes and a much-respected diplomat and excellent administrator, but not a feminist activist. Parliamentary quotas for women have been scrapped and no women were included in the committee that was formed in February to suggest a roadmap for a transition to a new democratic state and constitution. The National Council for Women has been effectively disbanded and there is no alternative counterpart to act as a national mechanism for women.

On the other hand, tens of political parties have been formed, each with a women's committee and all formed with the significant involvement of women who hold key positions in these new political parties (except perhaps the 'Salafi' parties). Moreover the activists, bloggers, protestors and agitators are still present on the political scene and are still voicing demands for democracy and against autocracy. Women's groups are also participating in vibrant debates about the new constitution and legal reforms and advocating legal and constitutional justice, including striving for civil personal status codes.

Contestations around women's strategic entitlements are taking place at one level and among various political actors and activists but the basic needs of women and families have also emerged after the revolution, in a new light.
The raison d'être for many development projects has been the provision of basic needs to poor Egyptians. The basic needs approach that has been at the core of much development work has provided a moral urgency to development interventions (Sholkamy 2009). Although basic rights to food, shelter, education, health and work were enshrined in the Constitution of 1971 (now suspended), the Egyptian state has never been able to keep up with the needs of a rapidly growing population and the rising rates of poverty and vulnerability. Egypt is not an aiddependent country and the majority of investments for development are national ones; however, funding for gender equity projects such as reproductive health, female political participation and microcredit tended to be driven, funded and/or promoted through international monies.

The funding for a great deal of gender work that aimed to fulfil both strategic and basic needs of women came through aid and grants and often pursued muddled objectives. For example, support for the creation of national women's 'machinery' supplied a strategic interest that gave women a voice in government but the projects of this machinery included microcredit, training, crafts, health promotion and other poverty alleviation interventions. The council did succeed in effective change at the macro-level and making a dent in patriarchal and unjust legal and administrative arrangements and regimes, but the urge to demonstrate an impact 'on the ground' and among the poor justified the work of the council and made their political impact palatable to the general public. Indeed even at the international and national level, feminists and gender and development bureaucrats have been using the sugar coating of basic needs to promote strategic ends! And, hence, the mingling of reproductive rights with the population control agenda, of women's right to work with economic growth and women's political participation with peace building and democratisation. This mix has created unlikely alliances including one between proponents of neoliberal agendas and feminism (Sholkamy 2009). ${ }^{2}$

This alignment of interests, however, has its limits. And nowhere are these limits more evident than in the poverty alleviation debate. The conflation of poverty alleviation and citizen empowerment (particularly women's 
empowerment) may make sense to the development project but not necessarily to that of philanthropy. Development as freedom, to borrow a term that is much celebrated, and freedom from poverty or need are not the same objectives. These two approaches belong to divergent, at times contradictory philosophical, moral and political traditions. Freedom from want can supply people with their basic needs but can also place them in the precarious positions of dependency and patronage.

Development as freedom means freedom from want and freedom from political injustice and dependence. Thus, access to information in India became an anti-poverty intervention as the Right to Information Act became the bedrock for more transparent and rights-based social interventions. Development paradigms are critically subjected to innovative political and scholarly thinking. This literature creates new parameters for new thinking and innovative action. Unfortunately, the world of philanthropy is not similarly constrained by dominant political discourse. Philanthropy is not subject to the regime of rights and entitlements. It can choose to confirm hierarchical relationships or craft client patron ones, since compliance with rightsbased approaches is optional for philanthropists.

\section{Equality 'up for grabs'}

The transitional period will end after the parliamentary and presidential elections take place in 2011/12 and culminate in a new constitution. Meanwhile, the scene is both stagnant and strange. The air is suffused with a negative energy, thanks to persistent media campaigns that have focused on real and perceived corruption, lost money and injustices. Meanwhile, new and old oppositions are fragmented in their views and engagements with the future as per the discord concerning the position and decisions of the ruling Supreme Council of the Armed Forces (SCAF) and the limited interest or involvement they have in managing the transition. The current civilian authority (i.e. the government) also seems feeble and hesitant.

It is difficult to read beyond these parameters. This article will conclude with an account of the adjustments that will necessitate a response and transformation or revision of gender and development work in Egypt, although the situation could change quickly and undermine the validity of this analysis. There are three 'adjustments' that will shape and give meaning to Egypt's development path after the revolution.

The first is the impact of the revolution on the nature and identity of the future state and the challenge to civil society.

The second adjustment concerns the overhaul of women's representation and the situation of national 'machineries'. Women's groups need to also contend with the distinction between rights and needs, which will come to haunt development practitioners as they reformulate and reorient their work.

The third concerns the position of women in a free society, one which does not necessarily espouse values of gender equality. There already is evidence of a paradigm shift whereby perceptions of the strategic and practical needs and rights of women are becoming less 'developmental' and more political on the one hand, insofar as political parties and agents are adopting this agenda, and on the other hand more charitable as philanthropy assumes the mantel of do-gooder and provider.

A climate of suspicion and angst reigns over questions of sovereignty and self-determination, which will impact the gender and development policies of Egypt, since the development world relies on civil society, donor funding and international agendas, and all three have been the subject of much speculation regarding their role in the revolution and where their allegiances lie. Of course state involvement with bilateral and multilateral donors still exists but the current situation will make it difficult to create new partners, more progressive or innovative programmes or creative projects because of this atmosphere of conspiratorial thinking. This situation is an example of the first adjustment and shows the need for a rapid reappraisal of the relations that govern development work.

The second adjustment involves the situation with national machinery and women's representation. The revolution discredited and decimated the National Democratic Party (NDP) and its acolytes. The National Council for Women was one of the institutions that fell first, since its premises were inside the building of the NDP, which was torched on Friday, 28 January 
2011. This symbolic and actual demise has made it difficult to resuscitate the organisation.

The council still exists but has relocated and is keeping a low profile until the term of its current board and secretary general end in December 2011. There is no alternative structure in place and attempts to create a commission for women have failed. The revolution has also brought politics back to life and with it have emerged tens of new political parties with women's committees and groups. These nascent organisations and groupings have yet to be studied or understood. At an anecdotal level, they seem to be constituted of feminist civil society activists and some academics. They may have an impact on representation and voice that has yet to become apparent. What seems to be clear however, is that quotas for women have been watered down to symbolic representations on party lists and those parties are not nominating women for fear of losing the elections.

The third adjustment concerns the rising poverty rates and the basic needs of women. The Egyptian economy is suffering in this time of turbulent transition. Some 60-70 per cent of Egyptians in the labour force are employed in

\section{Notes}

1 The age now is 15 years, unless children want to live with their father.

2 No cynicism is intended from this observation. At one level, these alliances have had a great

\section{References}

Batliwala, S. (2010) 'Taking the Power Out of Empowerment - An Experiential Account Buzzword', in A. Cornwall and D. Eade (eds), Deconstructing Development Discourse Buzzwords and Fuzzwords, Rugby: Practical Action Publishers: 111-29

Goetz, A.M. and Nyamu, C. (2008) 'Voice and Women's Empowerment: Mapping a Research Agenda', Pathways Brief 2, www.pathwaysofempowerment.org/resources_ pathways.html (accessed 13 October 2011) the informal sector and it is this sector that is suffering the most and benefiting the least from the revolutionary calls for social justice.

Philanthropic organisations are beginning to re-assume the mantle of social protection and provide alms, transfers and services and so create wide circles of clients and followers. The poor, specifically women, are being serviced by mostly religious organisations that do not use a rights framework to address people's needs. This may well be the worst outcome of the revolution, since this clientelism and making poverty a religious domain may set the gender agenda back decades because it reinforces stereotypical gender roles and a highly patriarchal gender division of labour.

What are the lessons of the revolution for the study of women's empowerment? This question needs further reflection but it is certain and clear that the revolution will change the world of development in Egypt in general, and will also have a profound impact on gender justice. There is already evidence of a paradigm shift, whereby perceptions of the strategic and practical needs and rights of women are becoming either less 'developmental' and more political or increasingly philanthropic and charitable.

impact on the realisation of gender justice and have managed to bring change to policy circles that led to actual commitment or lip service to the idea of social and gender justice.

Mitchell, T. (1995) Rule of Experts: Egypt, TechnoPolitics, Modernity, Berkeley: University of California Press

Sharmani, M. (2011) 'Analysis of Personal Status Laws in Egypt', unpublished report, Brighton: Pathways of Women's Empowerment Sholkamy, H. (2009) 'The Empowerment of Women: Rights and Entitlements in Arab Worlds', in M. Mukhopadhyay and S. Meer (eds), Gender, Rights and Development: A Global Sourcebook, Amsterdam: Royal Tropical Institute 